\title{
Herbivory on Posidonia oceanica: magnitude and variability in the Spanish Mediterranean
}

\author{
Just Cebrián ${ }^{1, *}$, Carlos M. Duarte ${ }^{1}$, Nùria Marbà ${ }^{1}$, Susana Enríquez ${ }^{2}$, \\ Margarita Gallegos ${ }^{3}$, Birgit Olesen ${ }^{4}$ \\ ${ }^{1}$ Centre d'Estudis Avançats de Blanes, C.S.I.C., Camí de Santa Bàrbara s/n, E-17300 Blanes, Girona, Spain \\ ${ }^{2}$ Freshwater Biological Laboratory, University of Copenhagen, 51 Helsingersgade, DK-3400 Hillerød, Denmark \\ ${ }^{3}$ Departamento de Hidrobiología, Universidad Autónoma Metropolitana-Iztapalapa, Michocán y Purísima, col. Vicentina, \\ AP 55-535, 09340 México D.F., México \\ ${ }^{4}$ Department of Plant Ecology, University of Aarhus, Nordlandsvej 68, DK-8240 Risskov, Denmark
}

\begin{abstract}
We examined the leaf age dependence, magnitude and variability of herbivore consumption of Posidonia oceanica (L.) Delile leaves in the Spanish Mediterranean. Two patterns of herbivore consumption along the life-span of $P$. oceanica leaves were found, namely a linear and a parabolic curve of cumulative leaf consumption versus leaf age, which are indicative of leaf-age-independent consumption rates and preference for mid-aged leaves, respectively. The fish Boops salpa contributed about $75 \%$ to the total herbivore consumption, and seemed to be responsible for the parabolic pattern of consumption with leaf age. Herbivory appeared to be a minor factor in the control of $P$. oceanica production since it only accounted, on the average, for about $2 \%$ of its leaf production. This percentage tends to increase in the northern populations of the Spanish Mediterranean as a result of the longer leaf life-span and associated higher cumulative consumption values, and the lower leaf production of these populations. It is concluded that, in spite of the low levels of herbivory on P. oceanica in the Mediterranean, this seagrass supports a high herbivore production due to its large primary production.
\end{abstract}

KEY WORDS: Herbivory · Posidonia oceanica - Boops salpa Spanish Mediterranean

\section{INTRODUCTION}

The seagrass Posidonia oceanica (L.) Delile forms dense meadows along the Mediterranean coast (Pérés 1967, den Hartog 1970, Boudouresque et al. 1984), where it contributes most of that system's primary production (Ott 1980, Domènec Ros et al. 1985). Herbivore consumption is believed to represent a minor fraction of $P$. oceanica production, which mostly enters the detritus food chain (Pergent et al. 1994) or is buried into the sediment (Romero et al. 1992). This contention relies, however, on a very few, local reports (Ott \& Maurer 1977, Velimirov 1984) and is in contrast with reports of high consumption rates in some meadows of $P$. oceanica (Laborel-Dequen \&

·E-mail: cebrian@azathoth.ceab.es
Laborel 1977, Kirkman \& Young 1981. Nedelec et al. 1981, Shepherd 1987) and observations of $P$. oceanica die-off during sea urchin outbreaks (Boudouresque 1987 ). Hence, the magnitude and variability of herbivory on $P$. oceanica on a broader scale have remained to be tested.

Consumption of even a small fraction of the large (500 to $3000 \mathrm{~g} \mathrm{DW} \mathrm{m}^{-2} \mathrm{yr}^{-1}$ ) production of Posidonia oceanica could theoretically support a large biomass of herbivores and, thus, be important at the ecosystem level in terms of secondary production. Moreover, herbivory could have important implications for the leaf production of $P$. oceanica, depending on whether it occurs regularly over all leaves on the shoot or preferentially on young leaves, since leaf nutrient content (Pirc 1985) and leaf contribution to the total shoot primary production decrease with leaf age (Ott 1980, Buia et al. 1992). Age-dependent patterns of leaf consump- 
tion should vary with differences in the relative abundance of different herbivores, which differ in their feeding strategies (Boudouresque 1987). Hence herbivory on young leaves should be more detrimental for $P$. oceanica production, as demonstrated for land plants (Schowalter et al. 1986). There is, therefore, a need to evaluate leaf age selectivity by the main herbivores of $P$. oceanica, to assess their potential effect on the production of $P$. oceanica leaves.
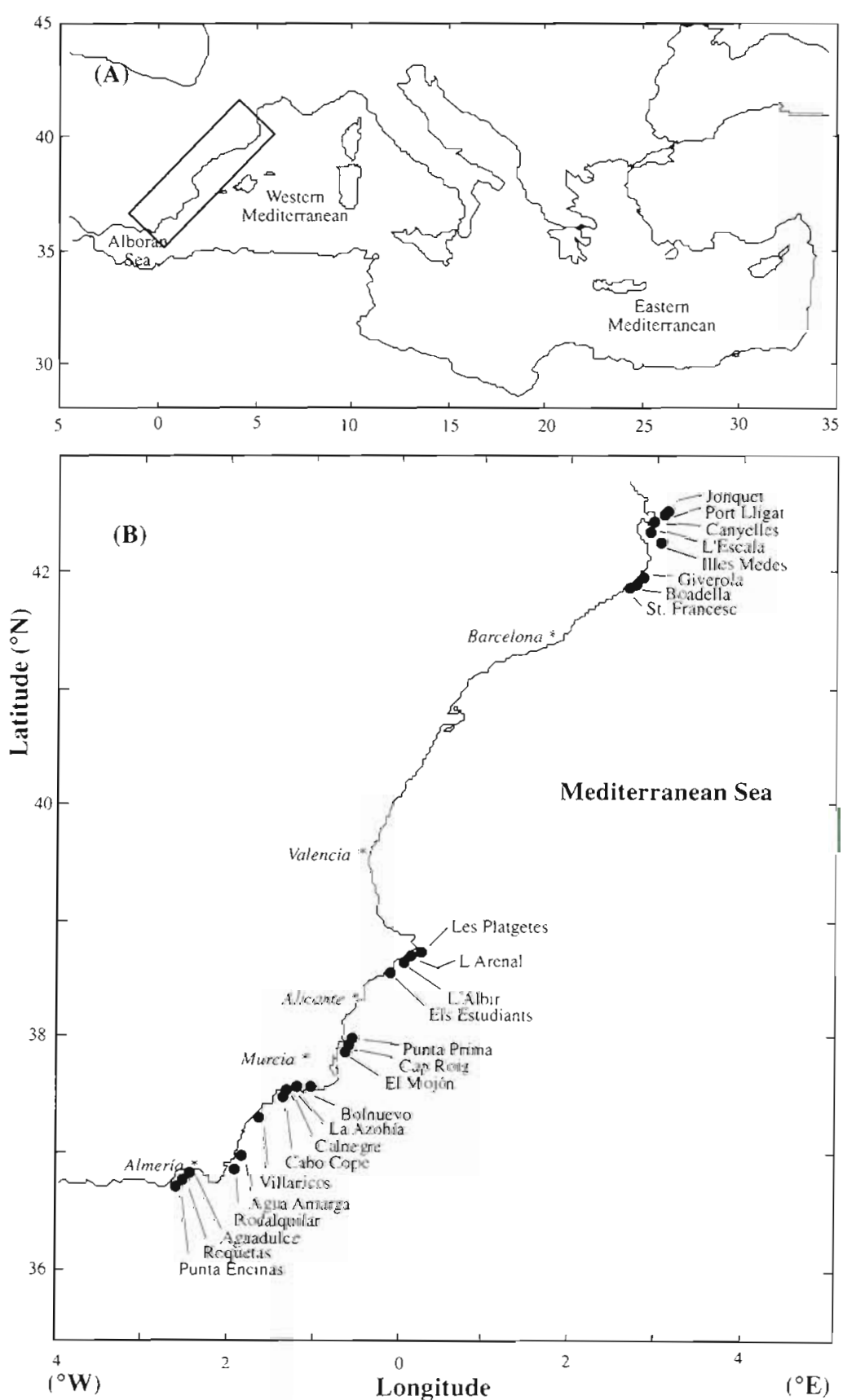

Fig. 1. Location of (A) the area studied in the Mediterranean Sea and ( $B$ ) the meadows examined along the Spanish coast
Here we quantify, based on a comparative study of 25 Posidonia oceanica populations along the Spanish Mediterranean, the magnitude and leaf-age-dependent patterns of herbivory on $P$. oceanica. We first examined the leaf age dependence of herbivore consumption, both by the entire herbivore community and by the 2 main herbivores (i.e. the fish Boops salpa and the sea urchin Paracentrotus lividus; Boudouresque 1987), and then estimated the magnitude and variability of herbivore consumption of $P$. oceanica leaves in the Spanish Mediterranean.

\section{METHODS}

We sampled 25 populations of Posidonia oceanica, located in the northern (41 to $43^{\circ} \mathrm{N}$ ) and the southern (36 to $38.30^{\circ} \mathrm{N}$ ) ranges of the Spanish Mediterranean coast (Fig. 1). These populations encompass a broad range of conditions, from lush, highly productive meadows to severely disturbed populations ( $N$. Marbà, C. M. Duarte, J Cebrián, S. Enriquez, M. Gallegos, B. Olesen \& K. Sand-Jensen 1995). The meadows were sampled at the depth of maximum density, which ranged between 4 and $12 \mathrm{~m}$. Fifty shoots of $P$. oceanica were collected from each population between June and July, the time of maximum biomass (Buia et al. 1992) and when the mean maximum leaf age is about $300 \mathrm{~d}$ (Cebrián et al. 1994), so that measurements of herbivory on those leaves represent cumulative values at nearly annual time scales (Sand-Jensen et al. 1994).

For all the sampled shoots, we measured the length, width and age rank of the leaves. On every leaf, herbivore consumption was quantified as the surface removed, as indicated by distinct scars left by herbivores when feeding on the leaves (Dimberger \& Kitting 1988 , Ogden 1990, Cebrián et al. 1994, SandJensen et al. 1994). Three species have been identified as the main herbivores of Posidonia oceanica (Boudouresque et al. 1984): the fish Boops salpa, the sea urchin Paracentrotus lividus and the isopod Idotea basteri. Differences in their feeding mechanisms result in distinct scars left on the leaves upon which they feed (Boudouresque et al. 1984), so that 
the consumption by each species can be quantified separately. Leaf surface was transformed to dry weight using the specific weight (i.e. $\mathrm{g} \mathrm{DW} \mathrm{cm}^{-2}$ ) of $P$. oceanica leaves measured in each population.

The quantification of leaf consumption from the leaf marks left by herbivores may somewhat underestimate herbivory, for the tips of intensively grazed leaves are probably more susceptible to breakage by wave action (Verlaque 1987), with the surface removed by herbivores being then partially sampled. In order to reduce the effects of this drawback, we attempted to account for high leaf consumption by sampling an elevated number of shoots per population (i.e. 50 shoots). Moreover, examination of the average length of intact leaves in every population revealed that this length, for an equivalent age class, was not very different from that of the non-intact leaves either bitten by herbivores (recognisable marks on the leaf) or broken by wave action (sharp cut or torn edge on the leaf blade). This suggests that the loss of grazed tips by wave action does not occur frequently and, thus, underestimation of leaf consumption due to this loss probably had little effect on our results.

The age of the Posidonia oceanica leaves measured was estimated from the leaf age rank and length, using an interpolation technique (Erickson \& Michellini 1957, Cebrián et al. 1994). This technique, based on the plastochrone interval concept, uses a geometrical approach to obtain a continuous estimate of the age of the youngest leaf in a shoot. The ages of the rest of the leaves in the shoot can be directly derived by adding, respectively, their age ranks to the age of the youngest leaf in that shoot (Cebrián et al. 1994). The continuous leaf age estimates are, however, in plastochrone interval units, and can be converted into chronological ones (days) from knowledge of the seasonality in the chronological duration of the plastochrone interval (Cebrián et al. 1994).

The patterns of herbivore consumption along the life-span of the Posidonia oceanica leaves were described by examining the relationship between the leaf dry weight removed by herbivores and leaf age, using a model which relates the cumulative consumption ( $C$, mg DW leaf ${ }^{-1}$ ) to leaf age ( $T$, days) (Jacobsen \& Sand-Jensen 1995). This model assumes that the cumulative leaf consumption must be a function of leaf age (i.e. time of exposure to herbivores) and selectivity by herbivores of a certain range of leaf ages. Provided there is no leaf age selectivity by herbivores, the cumulative leaf consumption should augment proportionally to leaf exposure to herbivores and, hence, should show a linear response with leaf age. Leaf age preference by herbivores should transform this linear trend into a parabolic one, showing a peak when herbivores select young leaves as a preference and a valley when they select old leaves. Thus, cumulative leaf consumption can be related to leaf age by the equation:

$$
C=a+b_{1} T+b_{2} T^{2}
$$

The equation was fitted using least-squares regression analysis ( $t$-test, $p<0.05$ ). A significant quadratic term (i.e. $b_{2} \neq 0$ ) indicates a non-linear pattern of cumulative consumption with leaf age, which may reflect either preference for young leaves $\left(b_{2}<0\right)$ or old leaves $\left(b_{2}>\right.$ 0). Non-significant quadratic terms (i.e. $\mathrm{H}_{0}$ : $\mathrm{b}_{2}=0, \mathrm{p}>$ 0.05 ) indicate populations experiencing constant consumption rates $\left(b_{1}\right)$ throughout the leaf life-span (Jacobsen \& Sand-Jensen 1995).

The leaf age at which herbivore consumption was initiated varied among populations, and thus the cumulative consumption curves were standardised in all the populations to the time of the onset of herbivory ( $m$, in days), by rearranging Eq. (1) as:

$$
C=b_{1}(T-m)+b_{2}(T-m)^{2}
$$

Accurate estimation of the age of Posidonia oceanica leaves by the interpolation technique requires knowledge of the seasonality in the chronological equivalence of the plastochrone interval (Cebrián et al. 1994). The error associated with the seasonal estimates of this equivalence results in an average value of $\pm 30 \mathrm{~d}$ around the leaf age estimates, which therefore sets a limit to the resolution of our leaf age estimates (Cebrián et al. 1994) Hence, the relationship between herbivore consumption and leaf age was derived after averaging herbivore consumption over $30 \mathrm{~d}$ consecutive leaf age intervals. This also proved useful in reducing errors due to the existence of intact and severely grazed leaves with similar ages.

Both the leaf consumption rate and the total consumption supported over the leaf life-span can be calculated from the leaf age consumption curve, as described by Cebrián et al. (1994). The leaf consumption rate is defined as the consumption of leaf surface by herbivores per unit time ( $\mu \mathrm{g}$ DW leaf $\left.\mathrm{f}^{-1} \mathrm{~d}^{-1}\right)$. This value is estimated as the slope $\left(b_{1}\right)$ of the linear relationship between cumulative leaf consumption and leaf age, if there is no evidence of leaf-age-dependent herbivory (i.e. non-significant $b_{2}$ parameter in Eq. 2), or as the average slope of the increasing portion of the parabolic pattern between cumulative consumption and leaf age otherwise. The total consumption supported by the leaves over their life-span ( $\mathrm{mg} \mathrm{DW} \mathrm{leaf}^{-1}$ ) is estimated as the maximal consumption value observed in the relationship between cumulative leaf consumption and leaf age (Cebrián et al. 1994, Jacobsen \& Sand-Jensen 1995).

The preference for leaves of different ages by the main herbivores was examined after averaging the cumulative patterns of leaf consumption by individual 
herbivores with leaf age for all the Posidonia oceanica populations where the particular herbivore species contributed $>10 \%$ of the total consumption. This criterion was established to ensure that there were enough scars from herbivory by the individual species to fit a significant pattern of cumulative consumption with leaf age in each of the populations sampled. Cumulative herbivory and leaf age (since the onset of herbivory) at each population considered, both for total and specific herbivory, were expressed as the percentage of the maximum leaf consumption and leaf lifespan, respectively, to standardise the values.

The estimate of total consumption over the leaf lifespan allows calculation of the leaf production per shoot removed by herbivores ( $m g$ DW shoot-1 $\mathrm{yr}^{-1}$ ), when multiplied by the average number of leaves produced annually per shoot (Sand-Jensen et al. 1994). The average number of leaves produced annually per shoot was calculated, following the methods outlined in Duarte et al. (1994), from the sequence of internodal length. The growth of vertical rhizomes proceeds through the continuous addition of internodes, the length of which shows a clear seasonality (Duarte et al. 1994). The average number of internodes in an annual cycle of internodal length represents, therefore, the average number of leaves they produce per year ( 1 internode $=$ 1 leaf produced; Duarte et al. 1994, Marbà et al. unpubl.). The sequences necessary to identify these annual cycles were constructed by digitising, under a dissecting microscope, the internodal lengths of 5 vertical shoots from each population. Leaf production per shoot ( $g$ DW shoot ${ }^{-1} \mathrm{yr}^{-1}$ ) was calculated as the product of the mean annual number of leaves produced per shoot and the mean maximum biomass reached by a leaf over its life-span (Duarte et al. 1994, Gallegos et al. 1994).

Patterns in the spatial variability of consumption of Posidonia oceanica leaves were examined by grouping the estimates of the populations within $1^{\circ}$ latitude, and then estimating the variance at large $\left(>1^{\circ}\right.$ latitude) and local $\left(<1^{\circ}\right.$ latitude) scale using analysis of variance and Tukey multiple comparison tests. Pearson correlation coefficients ( $r$ ) and least-squares linear regression analyses were used to describe the relationships between variables.

Table 1. Adjusted squared regression coefficient $\left(\mathrm{R}^{2}\right)$, time of the onset of herbivory, linear $\left(b_{1}\right)$ and quadratic $\left(b_{2}\right)$ coefficients of the consumption curve versus leaf age, and the maximum leaf consumption, consumed leaf production per shoot, percentage of leaf production consumed and percentage of consumption by Boops salpa in each of the populations examined. The adjustment of the consumption curve to our data was highly significant in all the populations $(p<0.01)$

\begin{tabular}{|c|c|c|c|c|c|c|c|c|}
\hline Population & $\mathrm{R}^{2}$ & $\begin{array}{l}\text { Age at onset } \\
\text { of herbivory } \\
\text { (m, days) }\end{array}$ & $\begin{array}{c}b_{1} \pm S E \\
(\mu g D W / \text { leaf } \\
\end{array}$ & $\begin{array}{c}b_{2} \pm \mathrm{SE} \\
(\mu \mathrm{gWW} \text { leat } \\
\left.\mathrm{d}^{-2}\right)\end{array}$ & $\begin{array}{l}\text { Maximum leaf } \\
\text { consumption } \\
\left.\text { (mgDW leat } t^{-1}\right)\end{array}$ & $\begin{array}{l}\text { Consumed leaf } \\
\text { production per shoot } \\
\left.\text { (mgDW shoot }{ }^{-1} \mathrm{yr}^{-1}\right)\end{array}$ & $\begin{array}{l}\text { Percentage of } \\
\text { leaf production } \\
\text { consumed }(\%)\end{array}$ & $\begin{array}{c}\text { Percentage of } \\
\text { consumption by } \\
\text { B. salpa }(\%)\end{array}$ \\
\hline Jonquet & 0.97 & 90 & $20.1 \pm 1.2$ & - & 4.8 & 31.5 & 4.4 & 53.6 \\
\hline Port Lligat & 0.92 & 90 & $11.3 \pm 1.2$ & - & 2.7 & 138 & 1.9 & 17 \\
\hline Canyelles & 0.96 & 210 & $34 \pm 3.3$ & - & 5.1 & 31.7 & 2.3 & 17.9 \\
\hline L'Escala & 0.95 & 60 & $37.7 \pm 7.1$ & $-0.09 \pm 0.06$ & 3.9 & 31.8 & 1.7 & 87 \\
\hline Illes Medes & 0.95 & 180 & $26.3 \pm 2.5$ & - & 4.7 & 38.1 & 3.7 & 73.2 \\
\hline Giverola & 0.98 & 120 & $25 \pm 1.5$ & - & 5.1 & 33.4 & 2.3 & 13.4 \\
\hline Boadella & 0.96 & 60 & $9.7 \pm 0.8$ & - & 2.3 & 16.4 & 1.6 & 31.6 \\
\hline St. Fransesc & 0.94 & 150 & $41.1 \pm 7.2$ & $-0.14 \pm 0.04$ & 3 & 27.4 & 1.9 & 60.7 \\
\hline Les Platgetes & 0.95 & 60 & $23.8 \pm 2.4$ & - & 3.6 & 23.4 & 1.5 & 96 \\
\hline L'Arenal & 0.85 & 90 & $26.6 \pm 4.2$ & - & 5.6 & 43.5 & 2.5 & 85.7 \\
\hline L'Albir & 0.92 & 90 & $11.2 \pm 1.6$ & - & 1.8 & 12.3 & 1.5 & 82.8 \\
\hline Els Estudiants & 0.87 & 150 & $68.3 \pm 13.3$ & $-0.22 \pm 0.07$ & 5.6 & 46.2 & 2 & 100 \\
\hline Punta Prima & 0.89 & 60 & $66.3 \pm 10$ & $-0.2 \pm 0.04$ & 5.5 & 37.6 & 1.8 & 85.4 \\
\hline Cap Roig & 0.73 & 60 & $11.7 \pm 2.5$ & - & 2.8 & 21.8 & 1 & 90.1 \\
\hline El Mojon & 0.92 & 90 & $51.3 \pm 7.9$ & $-0.21 \pm 0.05$ & 3.1 & 20.7 & 1.9 & 72.7 \\
\hline Bolnuevo & 0.95 & 90 & $48.1 \pm 6.9$ & $-0.18 \pm 0.04$ & 2.3 & 23.4 & 1.3 & 90.1 \\
\hline La Ahozía & 0.75 & 90 & $7.7 \pm 1.7$ & - & 1.6 & 12.8 & 1.7 & 48 \\
\hline Calnegre & 0.93 & 90 & $17.9 \pm 1.9$ & - & 3.8 & 28.2 & 1.7 & 79.8 \\
\hline Cabo Cope & 0.83 & 60 & $6.8 \pm 1.1$ & - & 1.6 & 14 & 0.8 & 84 \\
\hline Villaricos & 0.92 & 120 & $9.1 \pm 0.9$ & - & 2.2 & 20.2 & 0.9 & 97.5 \\
\hline Aguamarga & 0.97 & 90 & $33.2 \pm 3.5$ & $-0.19 \pm 0.03$ & 1.4 & 12 & 0.3 & 89.4 \\
\hline Rodalquilar & 0.88 & 90 & $66.7 \pm 13.1$ & $-0.28 \pm 0.08$ & 4 & 32.2 & 1.6 & 93.2 \\
\hline Aguadulce & 0.96 & 90 & $27.6 \pm 2.8$ & - & 5 & 40.1 & 0.9 & 95.4 \\
\hline Roquetes & 0.85 & 60 & $6.2 \pm 0.8$ & - & 1.6 & 13.6 & 1.4 & 38.2 \\
\hline P. Encinas & 0.95 & 150 & $14.9 \pm 1.7$ & - & 1.8 & 13.5 & 0.9 & 21.1 \\
\hline Mean & $1 \pm 0.01$ & $99.6 \pm 8.1$ & $28.1 \pm 3.9$ & $-0.18 \pm 0.02$ & $3.4 \pm 0.3$ & $25.6 \pm 2.1$ & $1.7 \pm 0.2$ & $68.2 \pm 5.8$ \\
\hline Range & 3 to 0.98 & 60 to 210 & 6.2 to 68.3 & -0.09 to -0.28 & 1.4 to 5.6 & 12 to 46.2 & 0.3 to 4.4 & 13.4 to 100 \\
\hline
\end{tabular}




\section{RESULTS}

Cumulative leaf consumption increased linearly with leaf age for most $(70 \%)$ of the populations (Table 1 , Fig. 2), indicating a constant rate of leaf consumption throughout the life-span of the leaves. The remaining populations $(30 \%)$ showed a parabolic increase of cumulative leaf consumption with leaf age, indicative of selective herbivory on mid-aged (100 to 200 d) leaves in these meadows (Sand-Jensen et al. 1994, Jacobsen \& Sand-Jensen 1995). In most of the populations $(80 \%)$ herbivory on leaves was initiated once these reached about 60 to $120 \mathrm{~d}$ (Table 1), and emerged from the protection offered by older leaves to either side of them.

The leaf consumption rate and the total consumption over the life-span of the leaves ranged, respectively, about 10 - and 5-fold among populations (Table 1). Populations with leaf-age-dependent herbivory (i.e. a parabolic increase of cumulative leaf consumption with leaf age) exhibited higher leaf consumption rates (ANOVA, $\mathrm{p}<0.01$ ). This difference did not result, however, in significant differences in the total amount of leaf material consumed over the life-span of leaves between the 2 patterns of cumulative leaf consumption with leaf age (ANOVA, $\mathrm{p}=0.42$ ).

Boops salpa contributed up to about $2 / 3$ of the total consumption in most $(70 \%)$ of the populations examined (Table 1), and was responsible, on the average, for about $68.2 \pm 5.8 \%$ of the herbivory, compared to
$30 \pm 6 \%$ for Paracentrotus lividus. Grazing by Idotea basteri always represented a minor fraction $(<5 \%)$ of the herbivory. Examination of the consumption pattern of $B$. salpa revealed a preference for mid-aged leaves (Fig. 3). Conversely, the consumption pattern of the sea urchin P. lividus is associated with a uniform consumption rate throughout the life-span of the Posidonia oceanica leaves (Fig 3).

Leaf production per shoot consumed by herbivores varied about 4 -fold among populations, ranging from 12 to $46.2 \mathrm{mg} \mathrm{DW}$ shoot $^{-1} \mathrm{yr}^{-1}$ (average $\pm \mathrm{SE}=25.6 \pm$ $2.1 \mathrm{mg} \mathrm{DW}$ shoot ${ }^{-1} \mathrm{yr}^{-1}$; Table 1). These values represent, on the average, about $1.7 \pm 0.2 \%$ of the leaf production per shoot (Table 1). Differences in both the absolute and relative amount of leaf production consumed were independent of differences in seagrass quality and vigour among populations, indicated respectively by nutrient concentrations in the leaf tissue and leaf production per shoot $(|\mathrm{r}|<0.25, \mathrm{p}>0.1$ for all the Pearson correlation coefficients; data for nutrient concentration from Marbà et al. unpubl.).

Most of the variation in the magnitude of leaf production per shoot consumed by herbivores occurred at spatial scales less than $1^{\circ}$ latitude (ANOVA, Fig. 4). In contrast, there were significant (ANOVA, $\mathrm{p}<0.05$ ), large-scale differences $\left(>1^{\circ}\right.$ latitude) in the percentage of leaf production per shoot consumed by herbivores, the populations in the northern $\left(42\right.$ to $\left.43^{\circ} \mathrm{N}\right)$ range supporting a higher relative herbivory than the southern populations ( $p<0.05 ;$ Fig. 4 ). The reasons for this may
Populations with leaf-age-independent herbivory

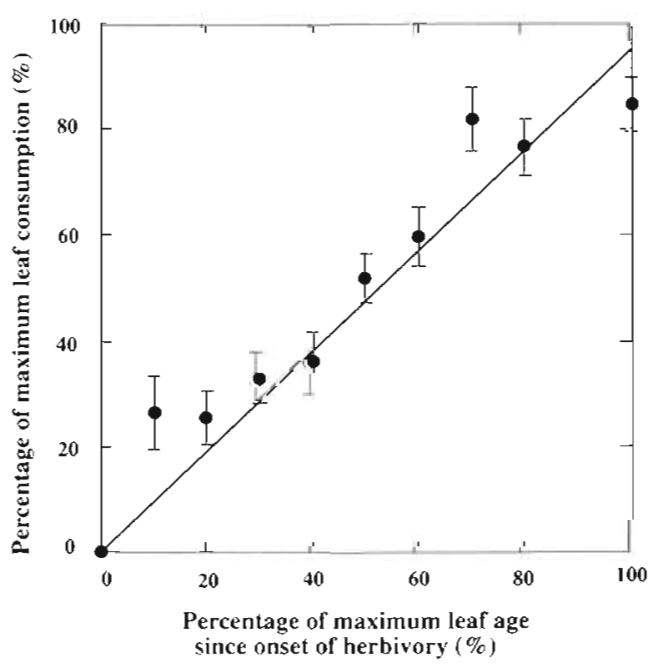

Populations with leaf-age-dependent herbivory

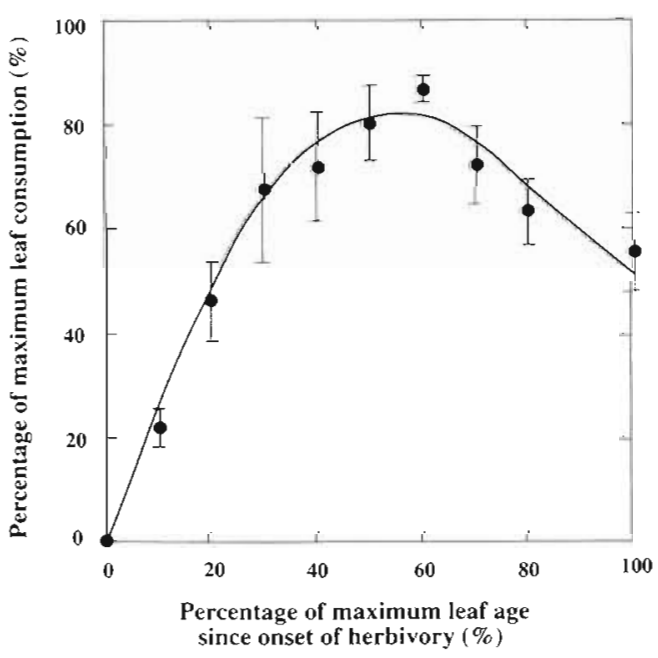

Fig. 2. Posidonia oceanica. Patterns of leaf consumption by the entire herbivore community over the life-span of seagrass leaves. Plots show, respectively, average linear (resulting from averaging all the populations with only significant linear coefficients, i.e. $b_{1}$; see Table 1) and parabolic (resulting from averaging all the populations with both significant linear and quadratic coefficients, i.e. $b_{1}$ and $b_{2}$; see Table 1) curves of leaf consumption versus leaf age of the $P$. oceanica meadows examined, after standardizing leaf consumption and age (since onset of herbivory) to $0-100 \%$ of their maximum values in each population. 

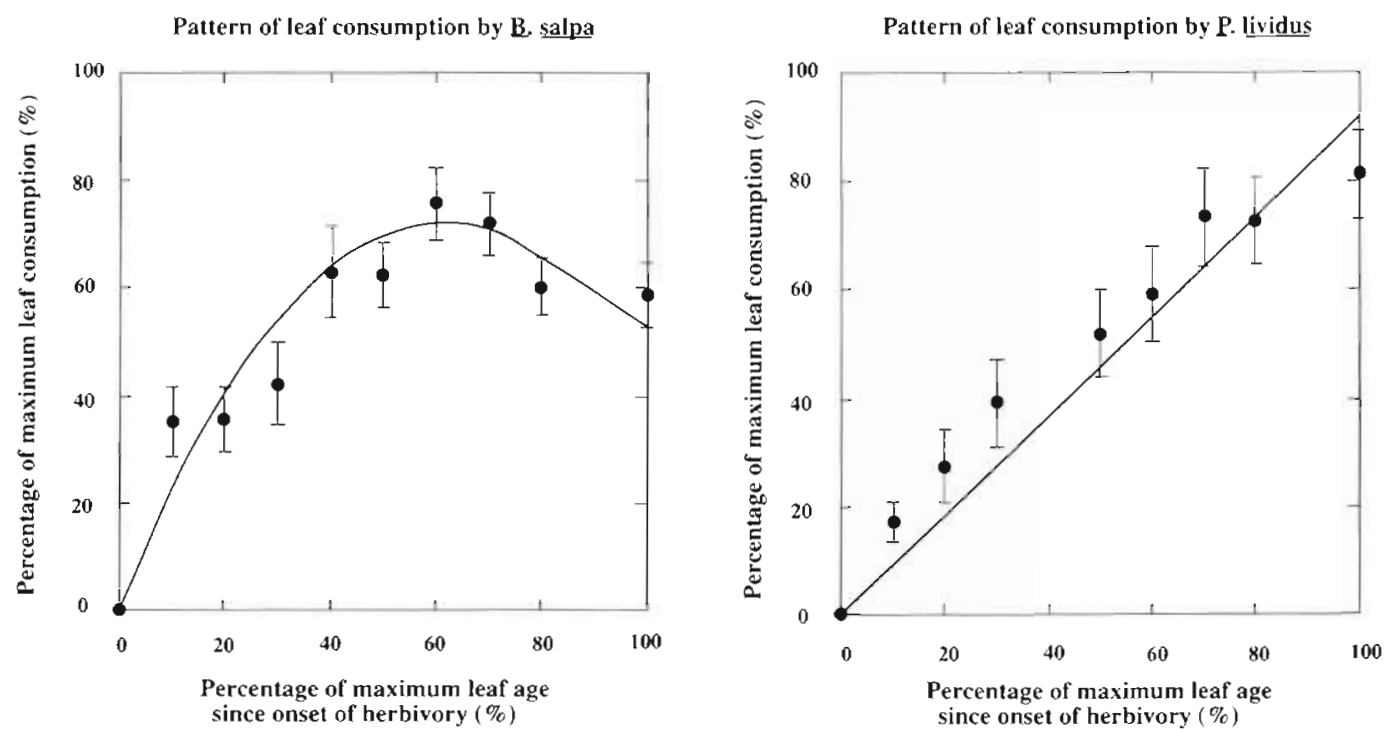

Fig. 3. Patterns of leaf consumption by Boops salpa and by Paracentrotus lividus over the life-span of Posidonia oceanica leaves Bars represent SE

partially be (1) the longer leaf life-span of the northern populations (Marbà et al. unpubl.), which increases the time leaf tissue is exposed to herbivores and, thus, leads to higher levels of consumed leaf production $(\mathrm{r}=$ $0.40, p<0.05$ ), along with (2) a greater tendency toward lower values of leaf production per shoot in the northern ( 42 to $43^{\circ} \mathrm{N}$, average $\pm \mathrm{SE}=1.2 \pm 0.2 \mathrm{~g} \mathrm{DW}$ shoot $^{-1} \mathrm{yr}^{-1}$ ) than in the southern populations (36 to $39^{\circ} \mathrm{N}$, average $\pm \mathrm{SE}=1.7 \pm 0.3 \mathrm{~g} \mathrm{DW}$ shoot ${ }^{-1} \mathrm{yr}^{-1}$ ).

The contribution by Boops salpa to the total consumption tended to increase with leaf production per shoot $(r=0.62, p<0.05)$, representing more than $95 \%$ of the total consumption in populations where leaf production per shoot was higher than $2 \mathrm{~g} \mathrm{DW} \mathrm{shoot}^{-1} \mathrm{yr}^{-1}$. The contribution by $B$. salpa to the total consumption varied significantly at spatial scales $>1^{\circ}$ latitude (ANOVA, $\mathrm{p}<0.05$; Fig. 4). The populations located between 37 and $39^{\circ} \mathrm{N}$ tended to support higher relative consumption rates by $B$. salpa than the populations between 41 and $42^{\circ} \mathrm{N}(p<0.1$; Fig. 4$)$, according to the tendency for a higher leaf production per shoot in the populations within 37 to $39^{\circ} \mathrm{N}$.
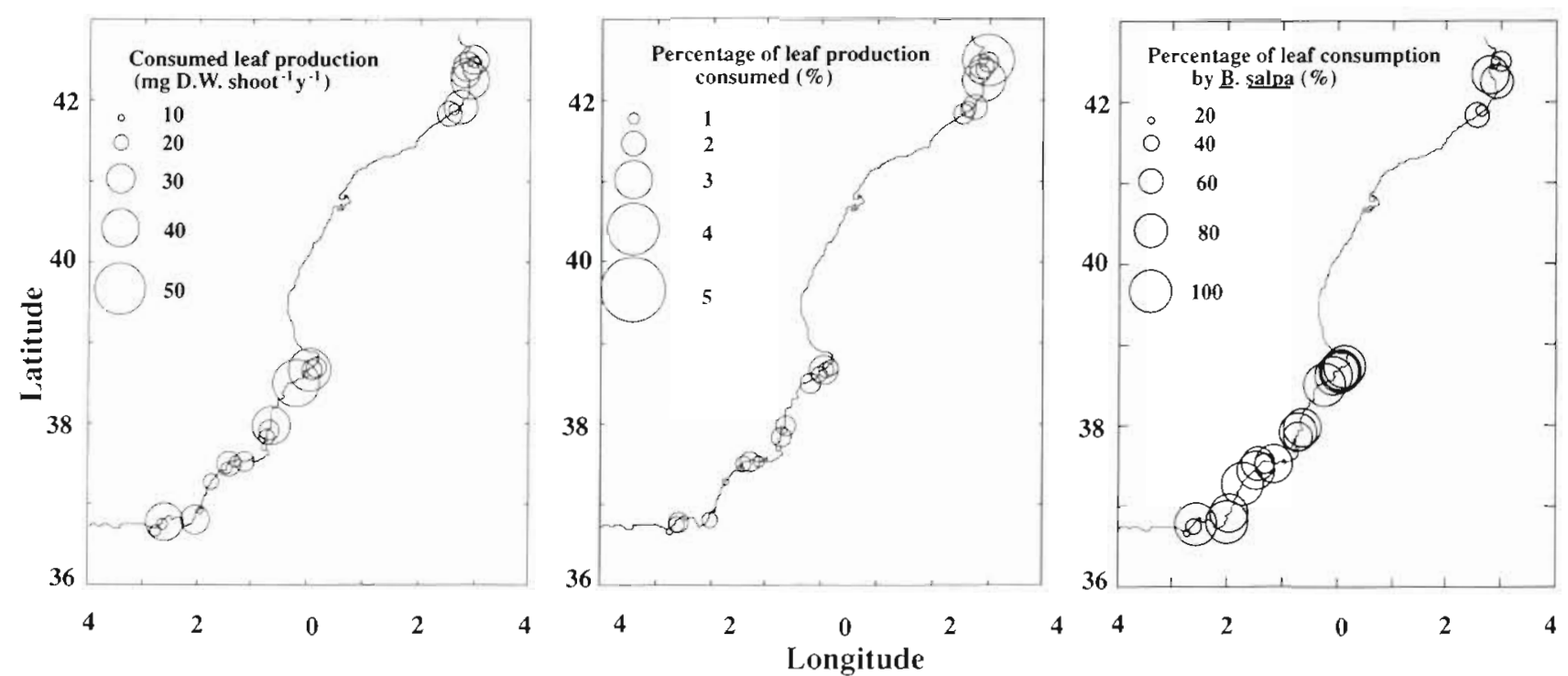

Fig. 4. Spatial variability of the consumed leaf production per shoot, the percentage of leaf production consumed and the percentage of leaf consumption by Boops salpa in the area studied 


\section{DISCUSSION}

The differences found between the consumption patterns by Boops salpa and Paracentrotus lividus over the life-span of the Posidonia oceanica leaves are consistent with their respective feeding behaviours. In situ observations of $B$. salpa feeding on $P$. oceanica (Velimirov 1984) and experiments on its feeding preference (Verlaque 1985) suggest that it preferentially consumes the intermediate (i.e. mid-aged) leaves on the shoot. In contrast, $P$. lividus attacks the leaves that are trapped by its spines during leaf flapping (Verlaque 1987), which should lead to a uniform pattern of leaf consumption with time of leaf exposure. Hence, $B$. salpa appears to be a selective herbivore, both because of its preference for mid-aged leaves (Fig. 3) and because it appears to select productive meadows.

The selection of mid-aged leaves by Boops salpa may be partially explained by the nutritional quality of the epiphytes these leaves support, which account for $25 \%$ of the B. salpa diet (Verlaque 1985, 1990). In spring, the epiphyte community on mid-aged leaves is dominated by gelatinous algae, which are very palatable to herbivores (Thayer et al. 1984), with a very small contribution of encrusting, less easily digestible algae (J. Cebrián, S. Enríquez, M. Fortes, N. Agawin, J. Vermat \& C. M. Duarte unpubl.). The contribution of encrusting algae to the total epiphyte biomass increases with leaf age, to reach a value of about $80 \%$ of the total epiphyte biomass on the oldest leaves (Cebrián et al. unpubl.), that would then be avoided by B. salpa. In addition, mid-aged leaves are the longest ones at the time of sampling (Ott 1980) and are, therefore, most easily accessible to $B$. salpa, which could also account for the selection of these leaves by $B$. salpa.

This study provides an assessment of the importance of herbivory as a loss factor of the production on Posidonia oceanica at large spatial scales (the Spanish Mediterranean coast), and temporal scales close to $1 \mathrm{yr}$ (the life-span of $P$. oceanica leaves). The range of our estimates of the percentage of $P$. oceanica leaf production consumed by herbivores $(0.3$ to $4.4 \%)$ is comparable to the few previous reports obtained over comparable time scales [(i.e. $9 \%$ reported by Ott \& Maurer (1977) and $2 \%$ reported by Velimirov (1984)]. Although there is evidence that herbivores may exert greater pressure on $P$. oceanica over restricted periods of time (Laborel-Dequen \& Laborel 1977, Kirkman \& Young 1981. Nedelec et al. 1981, Shepherd 1987), the data available indicate that, in general, herbivory should be a minor loss factor of the annual production of this species. It is possible, however, that the total loss of material caused by herbivores is greater than that estimated here if indirect losses, such as the possible increase in the likelihood of breakage of partially consumed leaves, associated with herbivory were accounted for. At any rate, the flow of $P$ oceanica carbon through herbivores is the smallest yet reported for a seagrass species. Available estimates indicate that herbivores consume, on average, $21.5 \pm 6.9 \%$ of seagrass leaf production (Cebrián \& Duarte 1994), and occasionally up to $50 \%$ of their primary production (Greenway 1976 , Valentine \& Heck 1991, Klumpp et al. 1993). This provides strong evidence for a negligible top-down control of $P$. oceanica production, compared to the much greater influence of resource availability (Pergent et al. 1994, Alcoverro et al. 1995). Moreover, the fact that the herbivore pressure on $P$. oceanica leaf production is independent of the seagrass leaf nutrient content points to the minor significance of the seagrass as a food source for herbivores and suggests they prefer other primary producers within the meadows, such as macro- or epiphytic algae.

The high leaf production reached by Posidonia oceanica, which may exceed $3000 \mathrm{~g} \mathrm{DW} \mathrm{m}^{-2} \mathrm{yr}^{-1}$ (Ott 1980), implies that even low percentages of $P$. oceanica leaf production consumed by herbivores should still allow considerable herbivore production. The mean shoot density for the studied zone was $706 \pm 84$ shoots $\mathrm{m}^{-2}$ (Marbà et al. unpubl.), which, multiplied by the mean leaf production per shoot $\left(1.7 \pm 0.1 \mathrm{~g} \mathrm{DW} \mathrm{shoot}^{-1} \mathrm{yr}^{-1}\right)$, yields an average areal leaf production value of about $1200 \mathrm{~g} \mathrm{DW} \mathrm{m}^{-2} \mathrm{yr}^{-1}$. Considering the average contribution of Boops salpa (65\%) and Paracentrotus lividus $(30 \%)$ to the total consumption of $P$. oceanica, and assuming assimilation efficiencies of 18.3 (Velimirov 1984 ) and $25 \%$ (Shepherd 1987) of the leaf material consumed, respectively, we estimated mean herbivore production to be about $2.7 \mathrm{~g} \mathrm{DW} \mathrm{m}^{-2} \mathrm{yr}^{-1}$ for $B$. salpa and $1.5 \mathrm{~g} \mathrm{DW} \mathrm{m}^{-2} \mathrm{yr}^{-1}$ for $P$. Lividus in the $P$. oceanica meadows of the Spanish Mediterranean. Extrapolation of these estimates to the total cover of $P$. oceanica in the Spanish Mediterranean (about $3.1 \times 10^{3} \mathrm{~km}^{2}$; Mas et al. 1993) allowed us to estimate the herbivore consumption of $P$. oceanica within the Spanish Mediterranean to amount to about $6.6 \times 10^{10} \mathrm{~g} \mathrm{DW} \mathrm{yr}^{-1}$, yielding a secondary production of about $8 \times 10^{9} \mathrm{~g} \mathrm{DW} \mathrm{yr}^{-1}$ for $B$. salpa

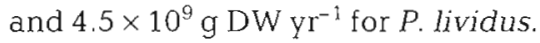

Our estimates of herbivore production in the Posidonia oceanica meadows of the Spanish Mediterranean are similar to previous reports on the production of Boops salpa (2.5 g DW m $\mathrm{g}^{-2} \mathrm{r}^{-1}$; Velimirov 1984) and somewhat lower than those on the production of Paracentrotus lividus (6.6 g DW m-2 $\mathrm{yr}^{-1}$; Shepherd 1987) in $P$. oceanica meadows elsewhere. Yet, they are among the highest values of herbivore production in aquatic systems (Cyr \& Pace 1993) even though they must somewhat underestimate herbivore production in $P$. oceanica meadows since macroalgae and epiphytes 
significantly contribute to the B. salpa (up to $30 \%$; Verlaque 1985) and P. lividus (25 to 50\%; Maggiore et al. 1987) diets within these meadows. In any case, herbivore production in $P$. oceanica meadows appears to be much lower than that in tropical seagrass meadows, where it may range from 8.5 to $18.5 \mathrm{~g} \mathrm{DW} \mathrm{m}^{-2} \mathrm{yr}^{-1}$ for the bucktooth parrotfish Sparisoma radians (Greenway 1976, Thayer et al. 1984) and from 7.2 to $52.1 \mathrm{~g}$ DW $\mathrm{m}^{-2} \mathrm{yr}^{-1}$ for some tropical sea urchins (Thayer et al. 1984, Klumpp et al. 1993). These differences appear to be attributable to higher herbivore consumption rates (Thayer et al. 1984) and assimilation efficiencies (Klumpp et al. 1989) in tropical seagrass systems. In fact, tropical seagrass meadows are thought to support one of the most abundant herbivore populations of all marine systems (Kikuchi \& Pérès 1973, Ogden 1976, 1980).

The low fractional consumption of the primary production of Posidonia oceanica points to an important transfer of $P$. oceanica carbon via detrital food webs. Indeed, existing evaluations of $P$. oceanica carbon budgets identify litterfall as the dominant path of the fate of $P$. oceanica primary production, channelling, on average, $70 \%$ of it (Ott \& Maurer 1977, Pergent et al. 1994). The detrital flow of $P$ oceanica primary production must have a strong bearing on the trophic flux within these seagrass meadows along with other food sources, such as epiphytes on the seagrass, which have been identified as being of major importance (Templado 1984, Zupi \& Fresi 1984). We hypothesise that the detritivore community maintained by the $P$. oceanica production and which is at the base of the food web (Pérès 1967, Zupi \& Fresi 1984) must have a considerable importance for the trophic role of the seagrass meadow, as has been shown for some tropical seagrass communities (Ogden 1980, Harrison 1989, Klumpp et al. 1989, 1993).

In conclusion, herbivores consume about $2 \%$ of Posidonia oceanica leaf production in the Spanish Mediterranean, which is one of the lowest values yet reported for seagrass communities. Therefore, herbivory plays a minor role in the production ecology of $P$. oceanica, suggesting that other processes, such as resource limitation, must control it. However, because of the high leaf production reached by $P$ oceanica, even such a small percentage of consumed leaf production supports a high herbivore production compared to most other ecosystems, except tropical seagrass meadows. Therefore, P. oceanica beds, although channelling most of the primary production through the detritivore foodweb, support a high production of herbivores in the Mediterranean.

Acknowledgements. This study was funded by a grant from the Fundacion Ramon Areces to C M.D. and by the Project AMB93-0118 of the Spanish Commission of Science and
Technology (CICYT). We thank E. McPherson, A. Gordoa and J. Borum for useful comments, G. Duarte and S. Agustí for field and laboratory assistance, J. Cebrián and H. Vallès for hospitality, and the Dirreccio General de Parcs of the Generalitat Valenciana for providing access to their facilities in Calp. The authors are also indebted to Dr Manceau for intense relief during field work

\section{LITERATURE CITED}

Alcoverro T, Duarte CM, Romero J (1995) Annual growth dynamics of Posidonia oceanica: contribution of largescales versus local factors to seasonality. Mar Ecol Prog Ser 120:203-210

Boudouresque CF (ed) (1987) Colloque international sur Paracentrotus lividus et les oursins comestibles. GIS Posidonie, Marseille

Boudouresque CF, Jeudy de Grissac A, Olivier J (eds) (1984) I. International workshop on Posidonia oceanica beds. GIS Posidonie, Marseille

Buia MC, Zupo V, Mazzella L (1992) Primary production and growth in Posidonia oceanica. PSZN I: Mar Ecol 13:2-16

Cebrián J, Duarte CM (1994) The dependence of herbivory on growh rate in natural plant communities. Funct Ecol 8: $518-525$

Cebrián J، Marbà N, Duarte CM (1994) Estimating leaf age of the seagrass Posidonia oceanica (L.) Delile using the plastochrone interval index. Aquat Bot 49:59-65

Cyr H, Pace M (1993) Magnitude and patterns of herbivory in aquatic and terrestrial ecosystems. Nature 361:148-150

den Hartog C (1970) The seagrass of the world. North Holland Publ, Amsterdam

Dirnberger JM, Kitting CL (1988) Browsing injuries to blades of Halophila decipiens within a deep seagrass meadow. Aquat Bot 29:373-379

Domènec Ros J, Romero J, Balleteros E, Gili JM (1985) Diving in blue water. The benthos. In: Margalef $R$ (ed) Western Mediterranean. Pergamon Press Ltd, Oxford, p 234-295

Duarte CM, Marbà N, Agawin $N$, Cebrián J, Enríquez $S$, Fortes MD, Gallegos ME, Merino M, Olesen B, SandJensen K, Uri J, Vermaat J (1994) Reconstruction of seagrass dynamics: age determinations and associated tools for the seagrass ecologist. Mar Ecol Prog Ser 107:195-209

Erickson RO, Michellini FJ (1957) The plastochrone index. Am J Bot 44:297-305

Gallegos M, Merino M, Rodríguez A, Marbà N, Duarte CM (1994) Growth patterns and demography of pioneer Caribbean seagrass Halodule wrightii and Syringodium filiforme. Mar Ecol Prog Ser 109:99-104

Greenway M (1976) The grazing of Thalassia testudinum in Kingston Harbour, Jamaica. Aquat Bot 2:117-126

Harrison P (1989) Detrital processing in seagrass systems: a review of factors affecting decay rates, remineralization and detritivory. Aquat Bot 23:263-288

Jacobsen D. Sand-Jensen K (1.995) Variability of invertebrate herbivory on the submerged macrophyte Potamogeton perfoliatus. Freshwat Biol 34:357-365

Kikuchi T, Pérès JM (1973) Review paper for the consumer ecology working group. Intl Seagrass Workshop, National Science Foundation, Leiden

Kurkman H, Young P (1981) Measurement of health and echınoderm grazing on Posidonia oceanıca (L.) Delile. Aquat Bot 10:329-338

Klumpp D, Howard RK, Pollard DA (1989) Trophodynamics and nutritional ecology of seagrass communities. In Larkum A, McComb A, Shepherd S (eds) Biology of sea- 
grasses: a treatise on the biology of seagrasses with special reference to the Australian region. Elvesier, Amsterdam, p $395-475$

Klumpp DW, Salita-Espinosa JT, Fortes M (1993) Feeding ecology and trophic role of sea urchins in a tropical seagrass community. Aquat Bot 45:205-229

Laborel-Dequen F, Laborel J (1977) Broutage des posidonies a la Plage du Sud. Trav sci Parc natl Port-Cros 3:213-214

Maggiore F, Berthon JF, Boudouresque C, Lawrence J (1987) Données preliminaires sur le relations entre Paracentrotus lividus, Arbacia Lixula et le phytobenthos dans la Baie de Port-Cros (Var, France, Méditerranée). In: Bouderesque $C F$ (ed) Colloque international sur Paracentrotus lividus et les oursins comestibles. GIS Posidonie, Marseille, p 65-28

Mas J, Franco l, Barcala E (1993) Primera aproximación a la cartografía de las praderas de Posidonia oceanica en las costas españolas. Factores de alteración y de regresión. Legilasción Publnes espec Inst Esp Oceanogr 11:111-122

Nedelec $H$. Verlaque M. Diapoulis A (1981) Preliminary data on Posidonia consumption by Paracentrotus lividus in Corsica (France). Rapp P-v Réun Comm int Explor scient Mer Méditerr 27:203-204

Ogden J (1976) Some aspects of herbivore-plant relationships on caribbean reefs and seagrass beds. Aquat Bot 2: $103-116$

Ogden J (1980) Faunal relationships in Caribbean seagrass beds. In: Phillips R, McRoy C (eds) Handbook of seagrass biology - an ecosystem approach. Garland Press, New York, p 173-198

Ogden J (1990) Community structure and function: the influence of grazing. In: Phillips R, McRoy C (eds) Seagrass research methods. Monographs on oceanographic methodology 9. United Nations Educational, Paris, p 177-182

Ott J (1980) Growth and production in Posidonia oceanica (L.) Delile. PSZN I: Mar Ecol 1:47-64

Ott J, Maurer L (1977) Strategies of energy transfer from marine macrophytes to consumer levels: the Posidonia oceanica example. In: Keegan B (ed) Biology of benthic organisms. Pergamon Press, Oxford, p 493-502

Pérès JM (1967) The mediterranean benthos. Oceanogr mar Biol A Rev 5:449-533

Pergent G, Romero J, Pergent-Martini C, Mateo M, Boudouresque $C$ (1994) Primary production, stocks and fluxes in the Mediterranean seagrass Posidonia oceanica. Mar Ecol Prog Ser 106:139-146

Pirc H (1985) Growth dynamics in Posidonia oceanica (L.) Delile I: seasonal changes of soluble carbohydrates, starch, free amino acids, nitrogen and organic anions in different parts of the plant. PSZN I: Mar Ecol 6:141-165

This article was submitted to the editor
Romero J, Pergent G, Pergent-Martini C, Mateo MA, Regnier $C(1992)$ The detritic compartment in a Posidonia oceanica meadow: litter features, decomposition rates, and mineral stocks. PSZN I: Mar Ecol 13:69-83

Sand-Jensen K, Jacobsen D, Duarte CM (1994) Herbivory and resulting plant damage. Oikos 69:545-549

Schowalter TD, Hargrove WW, Crossley DA Jr (1986) Herbivory in forested ecosystems. Ann Rev Entomol 31 $177-196$

Shepherd A (1987) Grazing by the sea-urchin Paracentrotus lividus in Posidonia oceanica beds at Banyuls, France. In: Boudouresque CF (ed) Colloque international sur Paracentrotus lividus et les oursins comestibles. GIS Posidonie, Marseille, p 83-96

Templado J (1984) Las praderas de P. oceanica en el sureste español y su biocenosis. In: Boudouresque CF, Jeudy de Grissac A, Olivier $J$ (eds) I. International workshop on Posidonia oceanica beds. GIS Posidonie, Marseille, p $159-172$

Thayer GW, Bjorndal KA, Ogden JC, Willians SL, Zieman JC (1984) Role of larger herbivores in seagrass communities. Estuaries 7:351-376

Valentine JF, Heck KL (1991) The role of sea urchin grazing in regulating subtropical seagrass meadows: evidence from field manipulations in the northern Gulf of Mexico. J exp mar Biol Ecol 154:215-230

Velimirov B (1984) Grazing of Boops salpa L. on Posidonia oceanica and utilization of soluble compounds. In: Boudouresque CF, Jeudy de Grissac A, Olivier J (eds) I. International workshop on Posidonia oceanica beds. GIS Posidonie, Marseille, p 381-387

Verlaque M (1985) Note préliminaire sur le comportement alimentaire de Boops salpa (L.) (Sparidae) en Méditerranée. Rapp P-v Réun Commn int Explor scient Mer Méditerr 29: 193-196

Verlaque M (1987) Relations entre Paracentrotus Lividus (Lamarck) et le phytobenthos de Méditerranée Occidentale. In: Boudouresque CF (ed) Colloque international sur Paracentrotus lividus et les oursins comestibles. GIS Posidonie, Marseille, p 5-36

Verlaque M (1990) Relations entre Boops salpa (Linnaeus, 1978) (Téléostéen, Sparidae), les autres poissons brouteurs et le phytobenthos algal méditerranéen. Oceanol Acta $13: 373-388$

Zupi V, Fresi E (1984) A study of the food web of the Posidonia oceanica ecosystem: analysis of the gut contents of echinoderms. In: Boudouresque CF, Jeudy de Grissac A, Olivier J (eds) 1. International workshop on Posidonia oceanica beds. GIS Posidonie, Marseille, p 373-379

Manuscript first received: December 23, 1994

Revised version accepted: July 7, 1995 